\title{
An Assessment of Industry Views on International Business Prospects for Solar Thermal Technology
}

J. C. Easterling

September 1984

Prepared for

Sandia National Laboratories under a Related Services Agreement with the U.S. Department of Energy Contract DE-ACO6-76RLO 1830

Pacific Northwest Laboratory Operated for the U.S. Department of Energy by Battelle Memorial Institute 


\title{
DISCLAIMER
}

This report was prepared as an account of work sponsored by an agency of the United States Government. Neither the United States Government nor any agency thereof, nor any of their employees, makes any warranty, express or implied, or assumes any legal liability or responsibility for the accuracy, completeness, or usefulness of any information, apparatus, product, or process disclosed, or represents that its use would not infringe privately owned rights. Reference herein to any specific commercial product, process, or service by trade name, trademark, manufacturer, or otherwise, does not necessarily constitute or imply its endorsement, recommendation, or favoring by the United States Government or any agency thereof. The views and opinions of authors expressed herein do not necessarily state or reflect those of the United States Government or any agency thereof.

\author{
PACIFIC NORTHWEST LABORATORY \\ operated by \\ BATTELLE \\ for the \\ UNITED STATES DEPARTMENT OF ENERGY \\ under Contract DE-AC06-76RLO 1830
}

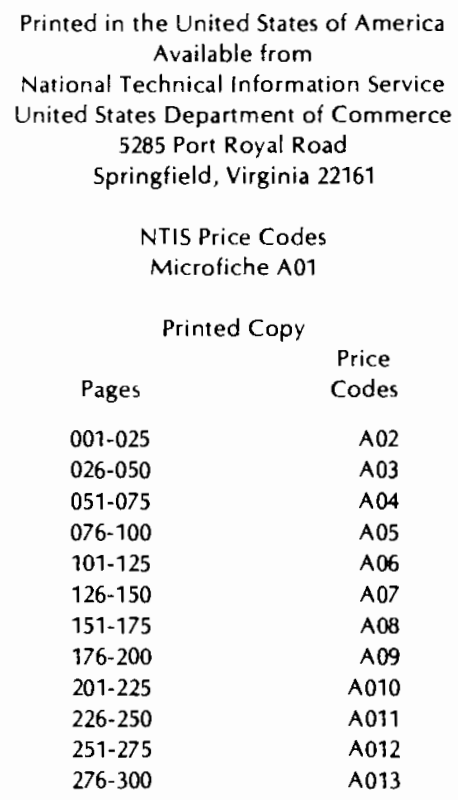


PNL -5255

UC -59

AN ASSESSMENT OF INDUSTRY VIEWS ON

INTERNATIONAL BUSINESS PROSPECTS

FOR SOLAR THERMAL TECHNOLOGY

J. C. Easterling

September 1984

Prepared for Sandia National Laboratories under a Related Services Agreement with the U.S. Department of Energy

Contract DE-ACO6-76RLO 1830

Pacific Northwest Laboratory

Richland, Washington 99352 


\section{ACKNOWLEDGMENTS}

The author would like to thank Joan Woodard, Tom Williams, and Jim Dirks at Sandia-Livermore for their guidance and support of this project. The author acknowledges the assistance of W. Bradford Ashton and David L. Brenchley for their valuable comments, which improved the final draft of this report substantially. For editing improvements, the author is indebted to Donna Kuick. All opinions and errors are the sole responsibility of the author.

Finally, a special expression of appreciation to Robert Smith (01in Chemical Company), Michael Seale (Babcock and Wilcox) and Walter Hesse (Entech, Inc.), whose efforts in directing the study are described in this report. 


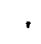

• 


\section{PREFACE}

This report was prepared to provide Sandia National Laboratories with information useful for its lead role in technical program integration for the U.S. Department of Energy, Division of Solar Thermal Technology. Pacific Northwest Laboratory (PNL) has conducted this study to assess the international business prospects for solar thermal technology. The findings and recommendations presented in this report are based upon interviews with U.S. solar thermal firms. 


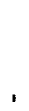




\section{EXECUTIVE SUMMARY}

This report contains a review of solar thermal industry viewpoints on their prospects for developing international business. The report documents the industry's

- current involvement in foreign markets

- view of foreign competition in overseas applications

- view of federal $R \& D$ and policy requirements to strengthen international business prospects.

The report is based on discussions with equipment manufacturers and system integrators who have a product or service with potential international demand. Interviews with manufacturers and system integrators were conducted by using a standard format for interview questions. The use of a standard format for questions provided a basis for aggregating similar views expressed by U.S. companies concerning overseas business prospects. A special effort was made to gather responses from the entire solar thermal industry, including manufacturers of line-focus, point-focus, and central receiver systems.

General, technical, economic, institutional, and financial findings are provided in this summary. In addition, Pacific Northwest Laboratory (PNL) recommendations are provided (based upon advice from the Solar Thermal Review Panel) for activities to improve U.S. solar thermal business prospects overseas.

GENERAL FINDINGS:

- The U.S. solar thermal industry is optimistic concerning future business overseas, but is dissatisfied with the quality and availability of certain types of information that are essential for planning overseas business activity. 
RECOMMENDATION:

The U.S. Department of Energy (DOE) should work with U.S. solar thermal firms to identify the types of key planning information needed by the industry to improve the planning of overseas business activities.

\section{TECHNICAL FINDINGS:}

- Within the technical area, an understanding of the status of foreign solar thermal R\&D is critical to estimating overseas business prospects.

- Information pertaining to the strength of the U.S. solar thermal technical lead over potential foreign competitors is viewed as critical to developing a successful business strategy abroad.

\section{RECOMMENDATION:}

DOE should collect data on foreign solar thermal R\&D activities and work with U.S. solar thermal firms to evaluate the impact of foreign $R \& D$ on the current U.S. technology advantage.

\section{ECONOMIC FINDINGS:}

- Most near-term export trade is expected to occur in the foreign assistance markets (i.e., markets where aid funds stipulate a preference for the purchase of U.S. goods).

- U.S. company production facilities are expected to be transferred overseas for technologies to be sold in commercial markets.

\section{RECOMMENDATION:}

Since its mission is to promote U.S. business competitiveness abroad, the Department of Commerce $(D O C)$ should assist U.S. solar thermal firms by supporting assessments of the competitive requirements of this technology in various foreign markets or market regions, i.e., which markets are accessible through export trade and which markets require overseas manufacturing. 
INSTITUTIONAL FINDINGS:

- Many federal programs intended to assist U.S. business with overseas trade have not been used by the solar thermal industry. For example, none of the U.S. firms interviewed have been involved in DOCsponsored overseas trade missions. None of the firms indicated awareness of the international market data available through the Bureau of the Census.

- Nontariff barriers are a major impediment to completing projects and complying with overseas sales agreements. The customs clearance process is a major nontariff barrier; it can add substantial time requirements to deliveries in foreign markets and cause major time delays in the completion of projects.

\section{RECOMMENDATION:}

Because existing federal programs can adequately meet requirements, no new recommendations are provided.

FINANCIAL FINDINGS

- Foreign government subsidies to foreign competitors are responsible for lost sales reported by U.S. solar thermal firms.

- Financial institutions specializing in export trade are well known to U.S. solar thermal companies.

- U.S. solar thermal companies' contact with these export trade financial institutions is minimal.

\section{RECOMMENDATION:}

There are a significant number of separate project financing agencies in development banks, the Export-Import Bank, and the Overseas Private Investment Corporation. The Departments of Agriculture and Commerce also offer support services that have potential implications for obtaining financing for overseas project sales. A special project or program effort should therefore be conducted by the DOC to coordinate overseas funding 
opportunities for U.S. solar thermal firms. "Operation Opportunity" could provide a model for implementing this type of program, but a special emphasis should be placed on the industry's need for financing energy projects overseas. (a)

(a) "Operation Opportunity" refers to a nationwide government-business seminar with the purpose of inforining U.S. business about federal resources to assist them in overseas trade. 


\section{CONTENTS}

ACKNOWLEDGMENTS $\ldots \ldots \ldots \ldots \ldots \ldots \ldots \ldots \ldots \ldots \ldots \ldots \ldots \ldots \ldots \ldots \ldots \ldots \ldots \ldots \ldots$

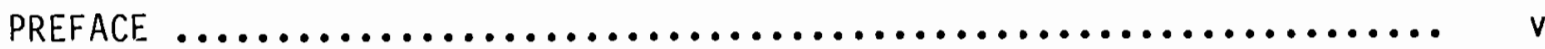

EXECUTIVE SUMMARY $\ldots \ldots \ldots \ldots \ldots \ldots \ldots \ldots \ldots \ldots \ldots \ldots \ldots \ldots \ldots \ldots \ldots \ldots \ldots \ldots$

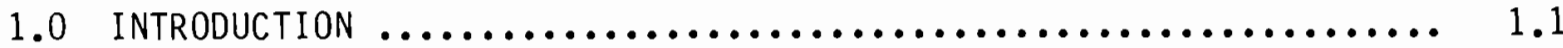

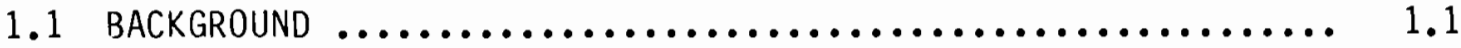

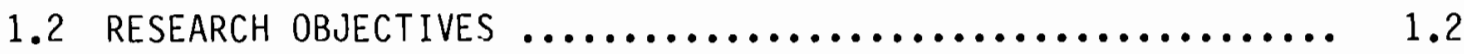

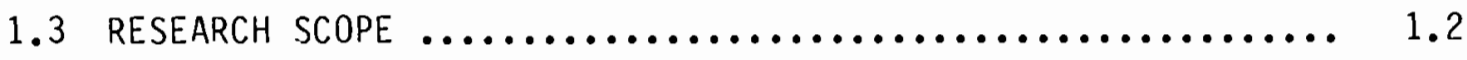

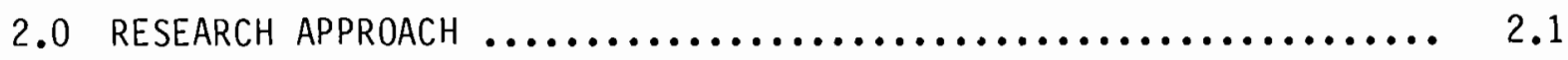

2.1 LiteratuRE REVIEW $\ldots \ldots \ldots \ldots \ldots \ldots \ldots \ldots \ldots \ldots \ldots \ldots \ldots \ldots \ldots \ldots \ldots \ldots \ldots \ldots \ldots$

2.2 INDUSTRY ADVISORY PANEL $\ldots \ldots \ldots \ldots \ldots \ldots \ldots \ldots \ldots \ldots \ldots \ldots \ldots \ldots$

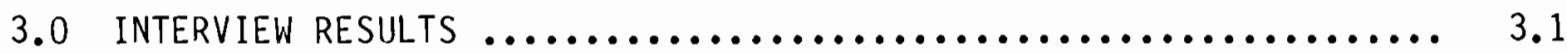

3.1 INTERNATIONAL SALES OR AGREEMENTS $\ldots \ldots \ldots \ldots \ldots \ldots \ldots \ldots \ldots \ldots \ldots . \ldots \ldots$

3.2 INTERNATIONAL EXPORT EVALUATION PLANS $\ldots \ldots \ldots \ldots \ldots \ldots \ldots \ldots \ldots . . \ldots \ldots$

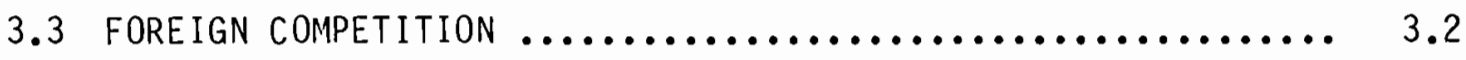

3.4 INTERNATIONAL BUSINESS/MARKET DEVELOPMENT STRATEGY ....... 3.3

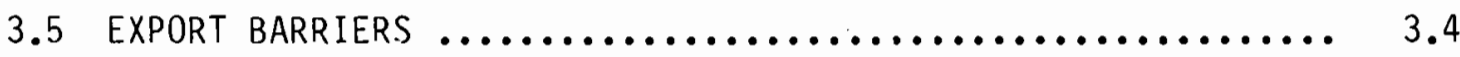

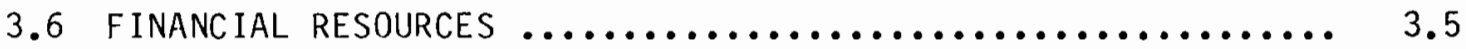

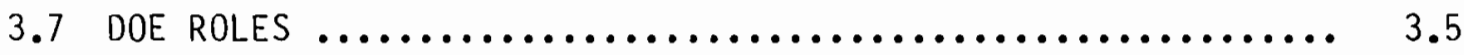

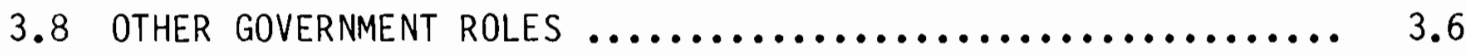

4.0 FINDINGS AND RECOMMENDATIONS $\ldots \ldots \ldots \ldots \ldots \ldots \ldots \ldots \ldots \ldots \ldots \ldots \ldots \ldots$

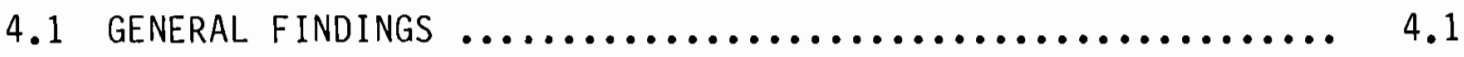

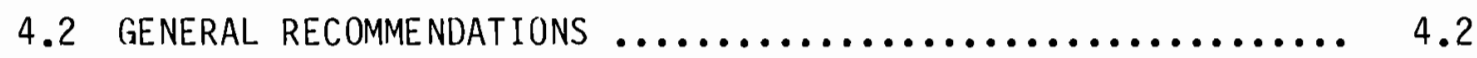

4.3 TECHNICAL FINDINGS $\ldots \ldots \ldots \ldots \ldots \ldots \ldots \ldots \ldots \ldots \ldots \ldots \ldots \ldots \ldots \ldots \ldots \ldots \ldots \ldots$

4.4 TECHNICAL RECOMMENDATIONS $\ldots \ldots \ldots \ldots \ldots \ldots \ldots \ldots \ldots \ldots \ldots \ldots \ldots$ 
4.5 ECONOMIC FINDINGS $\ldots \ldots \ldots \ldots \ldots \ldots \ldots \ldots \ldots \ldots \ldots \ldots \ldots \ldots \ldots \ldots \ldots \ldots \ldots, 4.3$

4.6 ECONOMIC RECOMMENDATIONS $\ldots \ldots \ldots \ldots \ldots \ldots \ldots \ldots \ldots \ldots \ldots, 4.4$

4.7 InSTITUTIONAL FINDINGS $\ldots \ldots \ldots \ldots \ldots \ldots \ldots \ldots \ldots \ldots \ldots \ldots, 4.4$

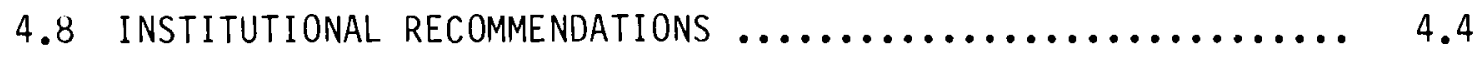

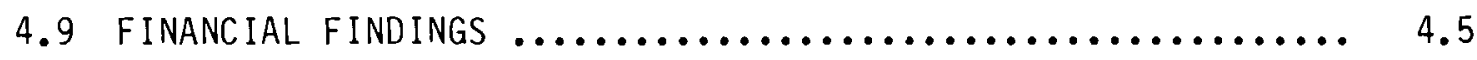

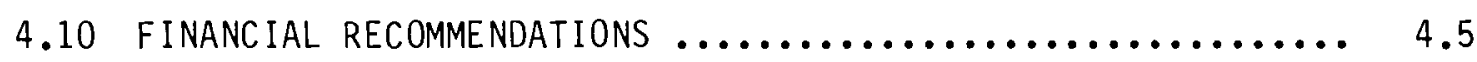

APPENDIX A - LITERATURE REVIEW $\ldots \ldots \ldots \ldots \ldots \ldots \ldots \ldots \ldots \ldots \ldots \ldots \ldots \ldots \ldots \ldots \ldots \ldots \ldots \ldots \ldots \ldots \ldots$

APPENDIX B - INDUSTRY QUESTIONNAIRE $\ldots \ldots \ldots \ldots \ldots \ldots \ldots \ldots \ldots \ldots \ldots \ldots . . .1$

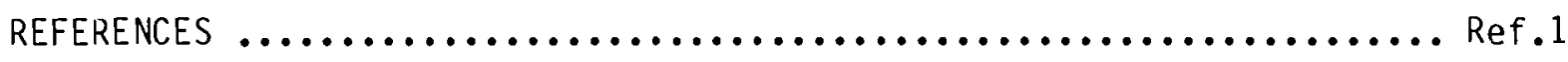

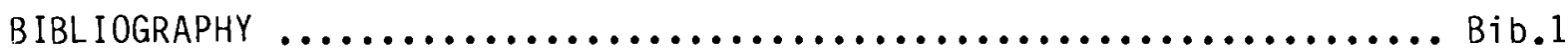




\subsection{INTRODUCTION}

A preliminary assessment of international business prospects from the perspective of U.S. solar thermal companies is presented in this report. A representative sampling of U.S. solar thermal companies provide current views on opportunities for solar thermal project sales abroad and on the constraints to realizing potential sales opportunities. Current views of U.S. solar thermal companies are documented in interviews; these views reveal major findings in technical, economic, institutional, and financial areas.

\subsection{BACKGROUND}

DOE priorities for solar thermal R\&D are based almost exclusively on technology improvements for U.S. domestic applications and sales. This domestic market focus is typical and usually appropriate for most new technologies, since most products are introduced into international markets only after they have attained substantial domestic market penetration.

This study, however, was conducted to investigate the importance of international sales in current business prospects for U.S. solar thermal companies. This emphasis on current overseas market potential is appropriate because international markets may precede domestic sales for U.S. solar thermal projects for the following reasons:

- Energy prices are high in many new energy markets overseas because price is very sensitive to the marginal cost of energy (EIA 1980).

- Many foreign markets do not have an extensive power distribution infrastructure. These conditions favor increased demand for smallscale, remote power applications such as solar thermal systems.

- Assessments of overseas markets for other renewable energy systems, such as wind energy systems (Griffith 1982) indicate that sales prospects abroad may well exceed sales in U.S. markets. If these findings apply to solar thermal systems as well, the importance of overseas markets is currently underestimated. 
While markets overseas may develop before domestic markets, there has been no documentation of the current understanding by U.S. solar thermal firms of market opportunities abroad or of the barriers, if any, to entering these markets. Adequate data on market forecasts for energy overseas and reliable methods of analysis comprehensive enough to handle international market issues do not exist. Consequently, this report does not attempt to provide an independent assessment of international market demand for solar thermal power plarits, but rather relies upon the views of U.S. solar thermal companies and documents their assessments of overseas business prospects.

\subsection{RESEARCH OBJECTIVES}

This report is preliminary in nature because its research objectives are limited to identifying and describing the perspective of solar thermal companies on the export potential for their products. It does not provide detailed research into such broad topics as the nature and size of potential international markets or the characteristics of mechanisms to supply U.S. technology overseas. However, this report does provide a basis for designing further evaluations of U.S. technology delivery systems and R\&D requirements to improve technology performance for various international markets and applications. Based on interviews with U.S. solar thermal companies, recommendations for resolving general, technical, economic, institutional, and financial constraints to overseas sales of solar thermal power plants are also presented.

\subsection{RESEARCH SCOPE}

The scope of the work was defined by three key questions involving international issues relevant to planning in the DOE Solar Thermal Technology Program:

- What is the status of industry involvement with foreign markets in technology development and sales?

- What do U.S. solar thermal companies require to enhance their competitive position against foreign companies in overseas markets? 
- What views are held by U.S. solar thermal companies regarding federal $R \& D$ and other government activities to enhance overseas business prospects?

In addressing these questions, views were obtained from the full range of types of U.S. solar thermal firms, such as component and systems manufacturers, including fairly even numbers of line-focus, point-focus, and central receiver systems manufacturers. 


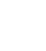




\subsection{RESEARCH APPROACH}

The research approach was divided into two steps. The first step involved identifying from existing research reports a current statement of major issues related to solar thermal business prospects abroad. The second step was to define the method for documenting the views of U.S. solar thermal companies interested in sales of solar thermal technology abroad.

\subsection{LITERATURE REVIEW}

A literature review was conducted to identify previous reports describing international business prospects for solar thermal technology. While no report duplicating the intent of this research effort was identified, many reports were located relevant to assessing supply and demand issues related to overseas sales of solar thermal technology. Since the purpose of this literature review was to prepare for discussions with key business decision makers in U.S. solar thermal firms, previous reports were organized in a framework convenient for discussing overseas supply and demand issues.

The details of this literature review are provided in Appendix A. While organized by supply and demand issues, the review is further defined by the following issues:

- Supply issues

- Status of R\&D abroad

- Product development for overseas applications

- Project evaluation outside the U.S.

- Product distribution to foreign markets.

- Demand issues

- Worldwide solar insolation

- Energy consumption forecasts for overseas markets

- Applications assessments abroad.

An assessment of overseas business prospects for solar thermal technology involves the use of primary data reference sources, numerous secondary sources, and a variety of periodical accounts of specific project developments and/or 
business activities. With these diverse sources of information, monitoring the status of business prospects is a major undertaking. For the most part, any one solar thermal business firm is unlikely to have the resources to monitor the flow of information in this area.

\subsection{INDUSTRY ADVISORY PANEL}

Fifteen U.S. solar thermal companies were interviewed to assess their knowledge, views, and business plans regarding the development of international markets. Al1 phases of this study were implemented with assistance from an industry advisory panel.

Members of the advisory panel who contributed throughout the project include:

- Walter J. Hesse, Entech, Inc., Vice President and General Manager

- Micheal L. Seale, Babcock and Wilcox, Sales Representative, Nuclear Equipment Division

- Robert E. Smith, 01 in Chemical Corporation, Assistant Director, Washington office

- Carl R. Williams, Lajet Energy Co., President and General Manager.

The first step in this study was to define an approach to documenting the status of overseas business planning by U.S. solar thermal firms. The industry advisory panel provided valuable guidance for structuring a format for interviews with key decision makers in U.S. solar thermal firms. The interview format is provided in Appendix B. Most of the interviews were conducted at large meetings of solar thermal industry representatives, such as conferences. For a small number of firms not present at prescheduled conferences, the questions listed in Appendix B were answered through mail and telephone correspondence.

The interviews were designed to emphasize eight major areas of inquiry suggested by the panel. They included issues ranging from the status of 
industry plans for overseas business activities to potential government roles in assisting this new industry with market penetration abroad. Areas of inquiry were defined as:

A. International Sales and Agreements

B. International Export Evaluation Plans

C. Foreign Competition

D. International Business/Market Development Strategy

E. International Barriers to Export

F. Financial Resources

G. DOE Roles

H. Other Government Roles

In addition, the panel assisted with identifying U.S. solar thermal companies to be interviewed, based on the need to involve a representative sampling of major solar thermal system designs. Thus, interviews were conducted with firms selling line-focus, point-focus, and central receiver system Companies involved in certain activities such as systems integration and thermal storage were also included. The fifteen U.S. solar thermal firms contacted and interviewed are listed below:

\begin{tabular}{|c|c|}
\hline Systems Integrator & Central Receiver \\
\hline $\begin{array}{l}\text { Babcock and Wilcox, Nuclear } \\
\text { Equipment Division }\end{array}$ & $\begin{array}{l}\text { Boeing Engineering and } \\
\text { Construction Company }\end{array}$ \\
\hline Black and Veatch Engineers & McDonnell Douglas Company \\
\hline Bechtel Group, Inc. & Martin Marietta Aerospace \\
\hline Thermal Storage & Arco Solar Industries \\
\hline Olin Corporation, Chemicals & Intersol Power Corporation \\
\hline Group & $\begin{array}{l}\text { Rockwell International, Energy } \\
\text { Systems Group }\end{array}$ \\
\hline Line-Focus & Point-Focus \\
\hline Acurex Corporation & Lajet Energy Company \\
\hline $\begin{array}{l}\text { Entech, Inc. } \\
\text { American Solar King, } \\
\text { Corporation }\end{array}$ & Power Kinetics, Inc. \\
\hline
\end{tabular}


Finally, the panel assisted in designing a framework for integrating interview results into categories convenient for making recommendations on future government program roles in assisting U.S. solar thermal firms with overseas business prospects. The framework for stating findings and recommendations involved sorting responses from the eight areas of inquiry cited above into five categories: general, technical, economic, institutional, and financial findings and recommendations. The panel considered these five categories to be more appropriate for defining areas of potential governmental and nongovernmental activities than the major issue areas defined for interview purposes. 


\subsection{INTERV IEW RESULTS}

This section provides an overview of the industry interviews by major areas of inquiry, which are

- International Sales and Agreements

- International Export Plans

- Foreign Competition

- International Business/Market Development Strategy

- International Barriers to Export

- Financial Resources

- DOE Roles

- Other Government Roles.

To ensure objectivity, highlights of interview comments are provided to demonstrate the validity of findings and recommendations.

\subsection{INTERNATIONAL SALES OR AGREEMENTS}

Most companies cautiously avoided any discussion of specific business negotiations or transactions. Major requirements identified for pursuing international sales or agreements include:

- Follow closely energy-related business activities overseas.

- Maintain a high sense of confidence about future overseas business prospects.

- Pursue overseas sales actively; only $30 \%$ of the U.S. thermal solar companies are actually seeking out foreign sales opportunities.

\subsection{INTERNATIONAL EXPORT EVALUATION PLANS}

Most solar thermal firms have not invested in operations overseas, but they have developed business plans for future project sales abroad. Their approach to planning varies with company size:

- Large corporations use in-house international marketing resources and the previous experiences of their business divisions with the exporting of established product lines. 
- Smaller companies rely upon outside consultants and trade publications for guidance in planning overseas activities.

When considering how these plans might be implemented in the future, the approach to business transactions is similar for small and large companies, with an emphasis on

- uniform licensing agreements

- use of established agents for foreign sales

- reliance on foreign distributors for delivery of goods.

\subsection{FOREIGN COMPETITION}

U.S. firms' perceptions concerning foreign competition are critical to determining whether overseas sales plans are ever implemented. Currently, the general perception of U.S. companies is that U.S. industry has a technological lead over the foreign competition. The nature of this advantage is subject to a wide range of opinions, including:

- The U.S. advantage is diminishing because of federal R\&D reductions.

- The U.S. lead is experience-based and not subject to immediate change. Despite the different views concerning future competitiveness, the elements identified as contributing to this U.S. comparative advantage are:

- superior U.S. technology product

- a substantial lead in project integration capabilities

- greater conversion efficiencies in U.S. technology products.

If U.S. firms were to lose their comparative advantage, most U.S. companies anticipate increased competition in potential solar thermal sales overseas to come from a rather small number of foreign competitors in Israel, Japan, France, and West Germany. For example, one Israeli solar thermal com-pany is currently out-competing U.S. firms even in U.S. markets, although the Israeli company's comparative advantage stems from government-subsidized financing, not from the technology.

In other cases, U.S. solar thermal firms are concerned about competition from other renewable technologies in overseas markets. The other renewable technologies most frequently identified are: 
- Photovoltaics

- Wind.

In general, most U.S. firms anticipate increased competition from foreign companies producing solar thermal technology abroad both in overseas markets and in markets within the U.S.

\subsection{INTERNATIONAL BUS INESS/MARKET DEVELOPMENT STRATEGY}

While most business/market development strategies are a product of inhouse efforts for the U.S. firms interviewed, almost without exception these firms have devoted resources to conducting formal exercises leading to a strategy for overseas sales. The primary reason for developing overseas business/ market strategies is to identify the business steps unique to meeting overseas market demand. Market demand for solar thermal technology has not been significant in the private sector, but foreign governments are frequently identified as the major source of overseas demand.

Special international marketing studies have not been widely commissioned by U.S. firms. Only one U.S. firm mentioned contracting a market research firm (Frost and Sullivan) to conduct a foreign market study. An important explanation for the current U.S. firms' approach to market analys is is probably the nature of foreign demand for solar systems. Most U.S. firms foresee sales abroad resulting not from consumer demand but from foreign government demand. Special international marketing studies are useful for identifying consumer demand abroad but probably less important where demand results primarily from government purchases.

Another aspect of a business strategy is the approach to contracting for production, distribution, or project installations for business operations abroad. U.S. solar thermal firms identified several contracting mechanisms common in overseas business activities, including:

- joint venture manufacturing overseas

- foreign licensing for manufacture or distribution 
- "turnkey"(a) installations

- export sales.

While joint venture and foreign licensing are mentioned most frequently, this list illustrates the alternative options being considered by U.S. firms to compete overseas.

Solar thermal firms include trade associations as resources when formulating an overseas business/marketing strategy. Only two international trade associations were mentioned:

- U.S. Export Council for Renewable Energy

- Nisho Iwai of Japan.

U.S. firms failed to mention any affiliation with the well known National Foreign Trade Council, Inc.

\subsection{EXPORT BARRIERS}

U.S. firms define two forms of export barriers: 1) a concern for duplication of U.S. technology by overseas companies, and 2) uncertain effects of institutional barriers on business transactions in overseas markets.

U.S. firms are least concerned about the threat of duplication of their technology by foreign competitors in markets where

- Foreign patent protection exists and provides protection against duplication.

- U.S. firms are confident about maintaining a technology development lead through continued R\&D progress.

Smaller U.S. firms have special concerns, however, and these include

- insufficient resources to secure foreign patent protection

- concern for excessive legal expenses where the host country's courts are partial towards local parties.

(a) "Turnkey" refers to a contract arrangement in which the seller agrees to build, and operate a facility, and often to train local personnel to operate the facility as well. 
Institutional barriers exist in two forms. Tariff restrictions are intended to raise revenue and restrict trade. Nontariff barriers hinder trade but without the monetary rationale of raising revenue. Fewer tariff than nontariff barriers were defined by U.S. solar thermal firms:

- Tariff barriers

- Japanese import duty restriction

- Nontariff barriers

- customs procedures and paperwork

- export license requirements

- foreign exchange restrictions

- foreign subsidies.

\subsection{FINANCIAL RESOURCES}

The discussion of financing centered not on private sources of capital for supporting overseas sales but on governmental or quasi-governmental financing options. While some U.S. firms identify their plans for financing through commercial or correspondent banking arrangements, most firms indicated a high level of awareness of U.S. government supported international or multinational funding agencies. Over $90 \%$ of U.S. firms expressed an interest in one or more of these international or multinational funding agencies.

\subsection{DOE ROLES}

The DOE role most often mentioned by U.S. firms involves technical exchange activities. While over half of those firms interviewed receive DOE information pertaining to international activities, only $13 \%$ of these firms have found this information useful to their interests in overseas business prospects. Identifying specific aspects of DOE information exchange found lacking by U.S. firms would require additional follow-up questions. It should be mentioned, however, that DOE does not have a strong legislative charter to perform support activities for U.S. firms engaged in overseas business. Other federal agencies, such as the DOC, perform this function. 
U.S. firms were asked to identify new support activities required for improving their overseas business prospects. In response, almost $70 \%$ of all firms specified the need for more reliable information on foreign R\&D developments. Many firms recommended R\&D surveillance as an additional role for $D O E$ to undertake.

\subsection{OTHER GOVERNMENT ROLES}

U.S. solar thermal firms made little reference to activities outside of DOE that might support business activities abroad. Only 20\% of U.S. solar thermal firms are aware of non-DOE activities. However, the DOC has recently completed a United States Export Development Plan for the Renewable Energy Industry (Garden 1983) for guidance of its own programs. In addition, there is a Memorandum of Understanding between the DOC and DOE providing for costsharing on activities to encourage export development of renewable energy technology.

In summary, new federal activities recommended by U.S. firms include:

- A quarterly foreign solar thermal R\&D report to be available to U.S. firms for use in their R\&D activities.

- A co-sponsored (with one or more foreign nations) international program for solar thermal systems performance and reliability testing.

- A regularly scheduled international workshop to encourage further exchange of information between U.S. and foreign firms on overseas business activities and project experiences. 


\subsection{FINDINGS AND RECOMMENDATIONS}

The views of U.S. solar thermal companies expressed in the interviews reveal several findings. For the most part, these findings indicate a strong need for additional activities to assist U.S. companies with solar thermal sales overseas. These findings and PNL recommendations for new activities to promote increased sales abroad for U.S. solar thermal companies are provided in this section.

Interviews with fifteen different U.S. solar thermal companies that included twenty-five standard questions resulted in almost 400 separate responses that were clustered into significant findings. Findings are presented in summary form under general, technical, economic, institutional, and financial categories. PNL recommendations based on these findings are listed after each statement of findings and define, where appropriate, some activity to resolve the constraints preventing U.S. solar thermal firms from pursuing international business prospects. In most cases the recommendations, if implemented, would substantially improve the availability of accurate business information and data required to assist U.S. firms in developing their business plans for overseas sales opportunities. The value of reliable information and data for planning purposes should not be underestimated; it is well established in international marketing that " a well-conceived and supported plan for overseas operation is essential for successful penetration of world markets" (Kahler and Kramer 1977, p. 79).

\subsection{GENERAL FINDINGS}

Findings indicate U.S. firms' concern regarding access to the reliable information required to plan a business strategy abroad in export trade or foreign manufacturing. In general, U.S. companies are knowledgeable about the problems and opportunities involved with achieving sales abroad, but express a need for support in obtaining accurate business data in order to develop their commercial activities in overseas markets. 


\subsection{GENERAL RECOMMENDATIONS}

DOE should work with U.S. solar thermal firms to identify the types of key information needed by the industry to improve the planning of overseas business activities. A fundamental requirement exists for accurate information to proceed with planning any overseas business strategy. U.S. solar thermal companies assign a high priority to a potential DOE role in creating a data base from which the information useful to identifying overseas business prospects can be easily retrieved.

Many of the following technical, economic, institutional, and financial findings and recommendations reveal a U.S. solar thermal industry concern for key information to support business planning requirements.

\subsection{TECHNICAL FINDINGS}

In interview responses, U.S. companies cite frequently their need for information on the status of foreign $R \& D$ on solar thermal technology. The firms refer frequently to the routine practice within U.S. energy laboratories of documenting $R \& D$ in reports and the organized distribution of these reports, as performed by the National Technical Information Exchange, for example. These activities support the transfer of U.S. R\&D results to foreign competitors. There are no comparable practices abroad to support U.S. access to the results of foreign solar thermal R\&D activities. U.S. companies thus view themselves as having a distinct disadvantage in maintaining a current under-standing of R\&D advances abroad.

U.S. companies are also concerned about maintaining a technical lead over foreign competitors in technology performance and reliability, mass production techniques, and advanced project management capabilities with solar thermal technology. Increased R\&D spending for solar thermal technology in some foreign countries, coupled with decreased U.S. R\&D spending, has U.S. companies concerned about their future competitive position in overseas solar thermal technology sales. 


\subsection{TECHNICAL RECOMMENDATIONS}

DOE should collect data on foreign solar thermal R\&D activities and work with U.S. solar thermal firms to evaluate the impact of foreign R\&D on the current U.S. technology advantage. Most U.S. firms identify this need to monitor R\&D developments abroad. There is no National Technical Information System equivalent outside the U.S. Hence, U.S. firms consider themselves at a distinct disadvantage. Their foreign competitors have excellent access to the results of R\&D funded by the U.S. U.S. firms do not have the same immediate access to $R \& D$ results funded by foreign governments.

\subsection{ECONOMIC FINDINGS}

U.S. solar thermal companies maintain an interest in two distinct market strategies. One strategy of market entry involves export sales and is targeted toward locating potential sales in special foreign assistance markets. Another strategy involves foreign licensing and overseas manufacturing of U.S. technology, and is designed to reduce manufacturing costs by locating production close to overseas markets in countries where labor costs and other business expenses are lower than the U.S.

Export sales of U.S. manufactured technology is a viable market strategy for projects sponsored by international agencies such as the Agency for International Development, the Export-Import Bank, and World Bank development banks. In some cases where these agencies are involved, there is a required preference for the purchase of U.S. technology. Where there is a specified preference for U.S. technology, the competitive economics of technology manufactured abroad are less of a factor.

Most U.S. companies foresee foreign licensing and overseas manufacturing as the market entry strategy necessary to compete with foreign manufacturers in overseas markets. It is the only strategy identified in interviews with companies in which the firms could project a reduction in sys.tems costs required to enter commercial markets abroad. 


\subsection{ECONOMIC RECOMMENDATIONS}

Since its mission is to promote U.S. business competitiveness abroad, the DOC should assist U.S. firms with assessments of competitive requirements of solar thermal technology in various markets or market regions, i.e., which markets are accessible through export sales and which require overseas manufacturing.

U.S. solar thermal firms do not have the resources to conduct studies to characterize distinct markets and market regions outside the U.S. The firms identify a real need for outside assistance for research to identify those markets where U.S. solar thermal technology may be competitive. The results from this research are essential to use in defining approaches to market entry by U.S. firms before planning any export sales or foreign licensing/manufacturing strategies for overseas business operations.

\subsection{INSTITUTIONAL FINDINGS}

U.S. companies are specific when identifying their concerns regarding institutional (non-economic) barriers to trade. For example, reference is made to existing Japanese import restrictions and other existing marketing or sales restrictions that could prevent entry into markets where favorable economics exist for solar thermal powerplant applications. However, many federal programs intended to overcome these barriers and to assist U.S. business with overseas trade have not been used by U.S. solar thermal firms. For example, none of the firms interviewed have been involved in DOC-sponsored overseas trade missions. Similarly, none of the firms indicated a knowledge of international market data available through the Bureau of Census. Other institutional concerns include nontariff barriers, such as the customs clearance process, which can add undefined time requirements to delivery of equipment in overseas markets and delay project completion dates substantially.

\subsection{INSTITUTIONAL RECOMMENDATIONS}

No new recommendations are provided, because existing federal programs can adequately meet requirements. 


\subsection{FINANCIAL FINDINGS}

In the few cases where U.S. companies have been close to finalizing sales of solar thermal systems in overseas markets, their bids have been turned down, not for lack of technical or economic merit, but because of their inability to match the favorable terms in subsidized loans offered by foreign competitors. These subsidized loans are long-term agreements with interest rates that are below commercial market interest rates due to involvement by foreign governments. This involvement may include government guarantee of repayment on the loan and or a subsidy on the difference between commercial interest rates and the lower interest rates offered in foreign government backed loan agreements. These special loan arrangements obviously favor overseas competitors in their bid proposals. To date, however, U.S. companies have been ineffective at gaining access to potential project financing funds within the various international development agencies or banks, although these firms are aware of overseas project financing options.

\subsection{FINANCIAL RECOMMENDATIONS}

Since the availability of financing affects the competitiveness of U.S. solar thermal business prospects abroad, the DOC should coordinate access to existing programs to finance overseas energy projects for U.S. solar thermal firms.

U.S. solar thermal firms identify the need for a collective strategy to pursue involvement in overseas project financing programs offered by international development agencies and banks. Subsidized financing from foreign governments has already prevented competition by U.S. firms. The major problem is the number of separate financing agencies in development banks, the ExportImport Bank, the Overseas Private Investment Corporation, and a number of special programs at the DOC and the Department of Agriculture. Too much time is required for each solar thermal firm to sort through all financing options.

The DOC's mission is to promote the competitiveness of U.S. business abroad and this mission could include program or project support to assist U.S. firms with eligibility for existing programs to finance energy projects overseas. 
APPENDIX A

LITERATURE REVIEW 

APPENDIX A

\section{LITERATURE REVIEW}

A literature review was conducted to identify previous reports describing international business prospects for solar thermal technology. While no report duplicating the intent of this research effort was identified, many reports were located relevant for assessing supply and demand issues related to overseas sales of solar thermal technology. Since this literature review was undertaken to prepare for discussions with key business decision makers in the U.S. solar thermal firms, previous reports were organized according to supply and demand issues. In the following review, reports are organized by specific supply and demand issues. The purpose of this review is to identify sources of information relevant to understanding these issues and identify a few problematic issues related to the use of current information sources.

\section{A.1 SUPPLY ISSUES}

Reports pertaining to supply issues are organized into the following subtopics:

- Status of R\&D abroad

- Product development for overseas applications

- Project evaluation outside the U.S.

- Product distribution to foreign markets.

\section{A.1.1 Status of R\&D Abroad}

There is at least one monthly periodical published outside the U.S. that tracks R\&D developments abroad. This periodical, Solar R\&D Update, is published by the International Energy Agency.

An obvious problem is the lack of a coordinated effort to report R\&D progress. There is no formal network for sharing information between R\&D laboratories or professional societies internationally on a routine basis. 


\section{A.1.2 Product Development for Overseas Applications}

Product developments of foreign competitors or competition in promoting solar thermal applications are not systematically followed in the U.S. In contrast, U.S. product development is tracked for overseas competitors in photovoltaic technology areas with support from DOE. This subject is also given attention in conference settings, such as the Second International Conference on Photovoltaic Business Development (Monegan, Ltd. 1983).

The major problem for U.S. solar thermal firms is the absence of information on product developments abroad.

\section{A.1.3 Project Evaluation Outside the U.S.}

More information is available on project evaluation than on either R\&D or product development activities. There are five countries active in six major solar thermal projects overseas. At least one project evaluation report exists for each project (SERI 1981).

A single source document, such as the Solar Thermal Technical Review (SERI 1984) acknowledging evaluation reports, provides a consolidated information source on these project reports.

\section{A.1.4 Product Distribution to Foreign Markets}

Several documents exist to provide insight and guidance on producing sales and delivering products abroad. These reports include A Guide to Exporting for U.S. Solar Companies (SERI 1981), Conference Proceedings on Financial Issues for International Renewable Energy Opportunities (Brookhaven 1981), and Solar Export Management Seminar Proceedings (SERI 1981a).

While these reports provide information of a general nature on approaches to overseas finance and sales requirements, they lack information on specific foreign market opportunities for U.S. solar thermal firms and case histories concerning past sales of solar thermal equipment abroad.

\section{A.2 DEMAND ISSUES}

Reports pertaining to demand issues are organized into the following subtopics: 
- Worldwide solar insolation.

- Overseas energy consumption forecasts.

- Applications assessments abroad.

\section{A.2.1 Worldwide Solar Insolation}

Worldwide solar insolation is reported in various literature sources with data collected by different measurement techniques. The major documents reporting solar insolation data include:

- Solar Radiation and Radiation Balance Data (USSR 1980)

- Solar Radiation Data in the European Community (Palz 1982)

- Solar Radiation Over India (Mani and Rangarajan 1982)

- Canadian Solar Radiation Workshop (Hay and Won 1978)

- Red Solarimetrica (Comision Nacional de Investigaciones Especiales)

A major problem with existing information sources will be resolved when data collection and reporting become standardized and integrated into a single information source.

\section{A.2.2 Overseas Energy Consumption Forecasts}

There are two major information sources on energy demand in foreign markets. One source is supported by the DOC in the form of information data bases and reports on demand for energy products in overseas markets. For example, the Foreign Traders Index is a data file on 150,000 importers or users of U.S. products in 143 different countries. The other major information source consists of trade and R\&D journals. Several publications are particularly useful for tracking sales of solar thermal equipment. They include:

- World Solar Markets (Financial Times 1984)

- Helios (University of College, Cardiff 1984)

- Newsletter (Commission of European Communities).

There is, however, no consistent form of reporting on overseas energy consumption forecasts, such as the Energy Information Administration Monthly Energy Report for markets within the U.S. The United Nations does publish statistics on energy demand by member countries in Yearbook of World Energy Statistics (United Nations 1980). 


\section{A.2.3 Applications Assessments Abroad}

Four of the most recent studies on application assessments abroad are concerned with small-scale, point-focus technology applications in rural or remote applications. There is an absence of similar assessment studies for larger scale solar thermal electric and thermal powerplant applications outside the U.S. The most recent review of assessments concluded:

"market assessments focus on low temperature, solar heating and cooling, and photovoltaic technologies."

The need to document applications outside the U.S. for large power requirements and assess the role of solar thermal technology in meeting these power needs is still apparent from existing reports. 
APPENDIX B

INDUSTRY QUESTIONNAIRE 



\section{APPENDIX B}

INDUSTRY QUESTIONNAIRE

Assessment of Solar Thermal Export Potential Industry Questionnaire

A. International Sales or Agreements

1. Are you looking to an export market for your technology?

2. Is the CEO of your business aware of the export market potential of your solar thermal technology?

3. Has your company characterized the export markets for your technology?

B. International Export Evaluation Plans

1. What sources of information or data do you use to define export strategy:

- Primary data such as foreign government business data, DOE foreign trade statistics, interviews in foreign markets, other? Please specify.

- Secondary data, such as DOE market assessments, DOE special reports on export trade or foreign sales opportunities, other? Please specify.

2. How do you believe your company could or should export your technology?

3. Have you identified any special comparative advantage associated with U.S. solar thermal technology in foreign markets? 
C. Foreign Competition

1. If you can, briefly explain the nature of competition with your technology in foreign markets.

2. Is this competition likely to penetrate future U.S. domestic markets? If so, when is this likely to occur?

3. How is the value of the dollar overseas affecting your perception of competition against foreign technology? How are you addressing yourself to price impacts of the dollar on your product in foreign markets?

D. International Business/Market Development Strategy

1. In cases of international experience with potential or actual foreign sales, please identify where, how, and why this experience occurred.

2. Have the buyers in these potential or actual foreign sales been private or government interests? 
3. Have you used private sector export trade or international business analysts such as Frost and Sullivan or A. D. Little to assist in the development of overseas business strategies?

4. What kinds of sales/service agreements are you providing or planning to provide to promote foreign sales?

5. What trade associations outside of the U.S. are you affiliated with and/or have been particularly useful for promoting foreign sales?

6. What U.S. trade associations are particularly useful for promoting foreign sales? 
E. International Barriers

1. Is a concern for foreign country duplication of U.S. technology important enough to prevent you from selling your technology abroad?

2. What tariff and nontariff measures present the greatest barriers to trade for solar thermal technology?

F. Financial Resources

1. What financial institutions offer opportunities to finance foreign sales?

- Export-Import Banks

- World Bank

- Regional Development Banks

- Asian Development Bank

- African Development Bank

- Caribbean Development Bank

- OPEC Institutions

- United Nations Development Program

- Other

2. Have you had recent contact with any of these financing or funding agencies regarding financing solar thermal projects?

G. Best DOE Role

1. Have you found DOE technical exchange activities useful in defining a business strategy leading to foreign trade/sales? 
2. Do you routinely receive information on DOE or other government agency sponsored international workshops?

3. How would you define what the DOE posture should be vis-a-vis foreign sales of solar thermal technology?

H. Other Government Roles

1. How do you maintain a current understanding of foreign solar thermal R\&D activities?

2. Are you confident about receiving the most relevant information on foreign R\&D developments pertaining to solar thermal technology?

3. What activities (if any) should the U.S. solar thermal programs implement to enhance industry access to foreign R\&D? 


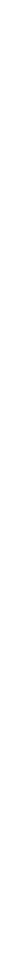




\section{REFERENCES}

Brookhaven National Laboratory. 1981. Proceedings of the Conference on Financial Issues for International Renewable Energy Opportunities. CONF 810723, Brookhaven National Laboratory, Upton, New York.

Comision Nacional de Investigaciones Especiales. Anuario 1979. Red Solarimetrica. Republica Argentina, Buenos Aires, Argentina.

Commission of the European Communities. Assorted monthly issues. Newsletter. Commission of European Communities, Luxembourg, Belgium.

Energy Information Administration (EIA). 1980. International Petroleum Annual 1978. U.S. Department of Energy, U.S. Government Printing Office, Washington, D.C.

Financial Times. August 1984. World Solar Markets. FT Publications, Inc., New York, New York.

Garden, L. September 30, 1983. United States Export Development Plan for the Renewable Energy Industry. International Trade Administration, U.S. Department of Commerce, Washington, D.C.

Griffith, S. K. December 1982. Foreign Applications and Export Potential for Wind Energy Systems. SERI/STR 211-1827, Solar Energy Research Institute (SERI), Golden, Colorado.

Hay, J. E., and T. K. Won. 1978. Proceedings: First Canadian Solar Radiation Data Workshop. National Research Council of Canada. Toronto, Canada.

Kahler, R., and R. L. Kramer. 1977. International Marketing. South-Western Publishing Company, Cincinnati, Ohio.

Mani, A., and S. Rangarajan. 1982. Solar Radiation Over India. Allied Publisher's Private Limited, New Delhi, India.

Monegan, Ltd. 1983. Proceedings from the Second International Conference on Photovoltaics Business Development. Monegan, Ltd., Geneva, Switzerland.

Palz, W., ed. 1982. Solar Radiation Data: Solar Energy R\&D in the European Community, Series F, Vol. 2. D. Reidel Publishing Co., Boston, Massachusetts.

Solar Energy Research Institute (SERI). 1981. A Guide to Exporting for U.S. Solar Companies. SERI, Golden, Colorado.

Solar Energy Research Institute (SERI). 1981a. Solar Export Management Seminar Proceedings. SERI, Golden, Colorado. 
Solar Energy Research Institute (SERI). 1981. Solar Energy Market Potential. SERI/SP-768-1054 (Brazi1), SERI/SP-768-1109 (France), SERI/SP768-1272 (Indonesia), SERI/SP-768-1102 (Phillipines). National Technical Information Service, Springfield, Virginia.

Solar Energy Research Institute (SERI). 1984. Solar Thermal Technical Review. SERI, Golden, Colorado.

University College, Cardiff. May, 1984. Helios. Department of Mechanical Engineering and Energy Studies, Cardiff, England.

United Nations Environment Programme. 1980. Proceedings of the International Workshop in Energy and Environment. United Nations, New York, New York.

U.S.S.R. 1980. Solar Radiation and Radiation Balance Data. U.S.S.R. State Committee for Hydrometeorology and Control of Natural Environment, Leningrad, U.S.S.R. 
B IBLIOGRAPHY

Allard, J. P., R. Genier, and M. Smakja. 1983. "The French Solar Tower Plant, THEMIS." In Solar Engineering - 1983: Proceedings of the ASME Solar Energy Division Fifth Annual Conference, ed. L. M. Murphy, pp. 294-300. The American Society of Mechanical Engineers, New York.

Alawi, H., et al., ed. 1983. Proceedings of the 1st Arab International Solar Energy Conference. Pergamon Press, Elmsford, New York, New York.

Annamalai, M., et a 1. 1982. National Solar Energy Convention (Solar Energy Society of India). DE-82905491. National Technical Information Service, Springfield, Virginia.

Argonne National Laboratories. 1980. Directory of Key Foreign Personnel. DOE/TIC-11302. National Technical Information Service, Springfield, Virginia.

Argarwa 1, A., et a1. August 1983. Competition and Collaboration: The Problems and Opportunities of Renewable Energy Technology Transfer to the Developing Countries. International Institute for Environment and Development, Washington, D.C.

Ashworth, J. H. 1979. Renewable Energy Sources for the World's Poor. SER I/TR51-195. National Technical Information Service, Springfield, Virginia.

Ashworth, J. H., and R. E. Meunier. 1979. International Development Assistance for Renewable Technologies: Current Programs and Institutional Requirements. SERI/TP-51-256. National Technical Information Service, Springfield, Virginia.

Ashworth, J. H., and J. W. Newendorffer. 1980. Matching Renewable Energy Systems to Village-Level Energy Needs. SERI/TR-744-514. National Technical Information Service, Springfield, Virginia.

Baker, A. F. May 1981. International Energy Agency Small Power Systems SSOS Project Review (January 1981). Sand 81-8216, Sandia National Laboratories, Albuquerque, New Mexico.

Beghi, G., ed. 1982. Thermal Energy Storage: Lectures of a Course Held at the Joint Research Center. D. Reidel Publishing Company, Boston, Massachusetts.

Behgi, G., ed. 1983. Performance of Solar Energy Converters: Thermal Collectors and Photovoltaic Cells. D. Reidel Publishing Company, Hingham, Massachusetts. 
Be11, C. R. 1979. Solar 0ptions in Central Europe. A Synthes is of Solar Technology Assessment and Contemporary Criteria in 1978 to 1979. IAASA-RR79-14. International Institute for Applied Systems Analysis, Laxenburg, Austria.

Biswas. M. R. and A. K. Biswas, eds. 1982. Alternative Strategies for Desert Development and Management in 4 volumes. Pergamon Press, Elmsford, New York.

Bloss, W. H., and G. Grassi, eds. 1982. Fourth E.C. P. V. Energy Conference. D. Reidel Publishing Company, Bingham, Massachusetts.

Bureau Energie Onderzoek Projecten, Patte (The Netherlands). 1982. Solar Energy in the Netherlands. Program of the Second Phase of the National Research Program on Solar Energy (1982-1985). DE 83901138. National Technical Information Service, Springfield, Virginia.

Butti, K., and J. Perlin. 1980. A Golden Thread: 2500 Years of Solar Architecture and Technology. Van Nostrand Reinhold Company, New York, New York.

Canas, Jose Simeon. 1979. Energy Perspectives for Underdeveloped Countries. PB-81-164444. Universidad Centroamericana, San Salvador, El Salvador. National Technical Information Service, Springfield, Virginia.

Carter, E. A., and G. S. Banholzer. June 1981. A Guide to World Insolation Data and Monitoring Networks. SERI/TR - 09119-1. Solar Energy Research Institute (SERI), Golden, Colorado.

Duffield, C. P. 1981. Solar Energy, Water and Industrial Systems in Arid Lands: Techno-Ecological Overview and Annotated Bibliography. University of Arizona, Tucson, Arizona.

Durand, H. L., D. Maycock and W. Palz, eds. 1981. Medium-Size Photovoltaic Power Plants. D. Reidel Publishing Company, Hingham, Massachusetts.

E. C. Contractors Coordination Meeting Proceedings. 1983. Solar Energy R\&D in the European Community. D. Reidel Publishing Company, Hingham, Massachusetts.

Farinelli, U., et al. 1980. The Evaluation of the Communities' Energy Conservation and Solar Energy R\&D Subprogrammes. Research Evaluation Report \#1. EUR-6902-EN. National Technical Information Service, Springfield, Virginia.

Glenn, B. H., and G. E. Franta, eds. 1980. Proceedings of the 1980 Annual Meeting of the American Section of the International Solar Energy Society. American Solar Energy Society, Boulder, Colorado.

Glenn, B. H., and G. E. Franta, eds. 1981. Proceedings of the 1981 Annual Meeting of the American Section of the International Solar Energy Society. American Solar Energy Society, Boulder, Colorado. 
Glenn, B. H., and W. A. Kolar, eds. 1982. The Renewable Challenge (Conference Papers of the 1982 Annual Meeting of the Solar Energy Society). American Solar Energy Society, Boulder, Colorado.

Gretz, J. "Solar Thermal Electricity Generation, EURELIOS, the 2 MW (el) Helioelectric Power Plant of the European Communities." International Journal of Solar Energy, Vol. 1 (No. 1), pp. 3-19.

The Hague. 1980. Annual Report (Stichting Energieonderzoek Centrum Nederland). DE82780403. National Technical Information Service, Springfield, Virginia.

Hal1, D. 0., and J. Morton. 1982. Solar World Forum. ISES 1981 Conference, Pergamon Press, Elmsford, New York.

Harigome, T., et al. August 1981. "Solar Thermal Electric Power Generation System in Japan." In Solar World Forum: Proceedings of the International Solar Energy Society Congress, edited by D. 0. Hall and J. Morton, pp. 3277-3281. Vo1.4. Pergamon Press, New York, New York.

Hawkins, D. 1980. Energy in Mexico. SERI/SP-763-595. National Technical Information Service, Springfield, Virginia.

Hawkins, D. 1980. Solar Energy in Australia. SERI/SP-763-717, National Technical Information Service, Springfield, Virginia.

Hawkins, D. 1980. Solar Energy in Italy. SERI/SP-763-718, National Technical Information Service, Springfield, Virginia.

Hawkins, D. 1981. Solar Energy in Argentina. SERI/SP-763-719, National Technical Information Service, Springfield, Virginia.

International Energy Agency (IEA). Monthly periodical. Solar R\&D Update. IEA, U.S. Department of Energy, Washington, D.C.

International Energy Agency. October 1980. An Introduction to Meteorological Measurements and Data Handling for Solar Energy Applications. U.S. Department of Energy, Washington, D.C.

Jacobius, T. M., et al. 1980. Baseline Study of U.S. Industry Solar Exports Final Report. SERI/SP-08331-1. National Technical Information Service, Springfield, Virginia.

Jaeger, F. 1981. Solar Energy Applications in Houses: Performance and Economics in Europe. Pergamon Press, Elmsford, New York.

Jet Propulsion Laboratory. February 20, 1982. Development and Application of Decentralized Energy Systems Utilizing Non-Conventional Energy Sources. Salojipally Project, Second Conference Report. Jet Propulsion Laboratory, Pasadena, California. 
Korzen, W. A., and C. F. Mueller. 1981. Technische Solarenergienutzung. Moeglichkeiten und Grenzen. Beispiel Desterreich. Verlag, Karlsruhe, West Germany.

Lim, B. P. 1981. Solar Energy Applications in the Tropics. D. Reidel Publishing Company, Hingham, Massachusetts.

Lof, G., et al. July 1966. World Distribution of Solar Radiation Report No. 21. Solar Energy Laboratory, University of Wisconsin, Greenbay, Wisconsin.

Martinex, A. R. 1981. Solar Cooling and Dehumidifying. Pergamon Publishing Company, Elms ford, New York.

Millhone, J. P., and E. H. Willis. 1981. New Energy Technologies and Their Commercialization, in 3 volumes. Springer Verlag, New York.

Munz, T. A. August 1981. "A Spanish 'Power Tower' Solar System, the Project CESA - 1." In Solar World Forum: Proceedings of the International Solar Energy Society Congress, Vo1. 4, edited by D. 0 . Hal1 and J. Morton, pp. 2931-2935. Pergamon Press, New York, New York.

National Academy of Sciences. 1981. Supplement: Energy for Rural

Development: Renewable Resources and Alternative Technologies for Developing Countries. National Academy of Sciences, Washington, D.C.

Ortabasi, U., et a1. 1983. Stand Alone Parabolic Dish Power Plants to Provide Electricity to Isolated Single Residences in Remote Areas. Solar World Congress, Perth, Australia.

Palz, W. 1981. Third E.C. Photovoltaic Solar Energy Conference. D. Reidel Publishing Company, Hingham, Massachusetts.

Pierson, H. 0., and A. Nahui. 1981. The Development of Solar Energy in Peru. SAND 81-0764. National Technical Information Service, Springfield, Virginia.

Rab1, A. September 1980. Yearly Average Performance of the Principal Solar Collector Types. SERI/TR 631/716, Solar Energy Research Institute, Golden, Colorado.

Secretaria de Asentamientos Humanos y Obras Publicas. 1980. Solar Energy Applications for Dwellings. PB-82-236969, National Technical Information Service, Springfield, Virginia.

Selzer, H. 1980. Third International Solar Forum. CONF-8006128, DGS Sonnenenergie Ver Tags GmbH, Munich, West Germany.

Shimada, K. 1983. Photovoltaic Research and Development in Japan. DOE/JPL.1012-80, National Technical Information Service, Springfield, Virginia. 
Solar Energy Industries Association. December 1982. International Solar Thermal Market Assessments: An Evaluation. DOE/AL/ 19929 T6, Solar Energy Research Institute, Golden, Colorado.

Solar Trade Association. Assorted monthly issues. Newsletter. Solar Trade Association, Ltd., London, England.

Stamboulis, C. 1981. Solar Energy in the 80's. Pergamon Press, Elmsford, New York, New York.

Thompson, P. June 1981. A Guide to Exporting for U.S. Solar Companies. SERI/SP 763-700, Solar Energy Research Institute, (SERI) Golden, CoTorado.

Thompson, P. and T. West. April 1981. Solar Export Management Seminar Proceedings. SERI/CP 763-1116, Solar Energy Research Institute, Golden, Colorado.

TPI, Inc. 1980. Solar Energy Pilot Study. First Followup Report. Committee on the Challenges of Modern Society. D0E/CS/30108, National Technical Information Service, Springfield, Virginia.

Turrent, P., et al. 1982. Solar Thermal Energy in Europe. D. Reidel Publishing Company, Boston, Massachusetts.

Twidel1, J. 1982. Energy for Rural and Is land Communities, II. Pergamon Press, Elms ford, New York.

U.S. Department of Commerce. Biweekly magazine, assorted issues. Business America. U.S. Government Printing Office, Washington, D.C.

U.S. Department of Commerce. Assorted daily issues. Commerce Business Daily. U.S. Government Printing Office, Washington, D.C.

U.S. Department of Commerce. Commercial NewS USA. Office of Event Management and Support Services, Washington, D.C.

U.S. Department of Energy. 1979. DOE/Solar Export Opportunities Workshop. SERI/TP-49-186, National Technical Information Service, Springfield, Virginia.

Valls, J., and R. B. Exel1. 1979. Applications of Solar Energy in South and Southeast Asia. DE-8290065, National Technical Information Service, Springfield, Virginia.

Veziroglu, T. N. 1981. Proceedings of the Miami International Conference on Alternative Energy Sources in 9 volumes. Hemisphere Publishing Corporation, Washington, D.C.

Veziroglu, T. N. 1981. Solar Energy: International Progress. Pergamon Press, Elmsford, New York. 
Williams, T. A., et al. May 1983. Solar Thermal Financing Guidebook. PNL-4745, Pacific Northwest Laboratory, Richland, Washington.

World Bank. 1980. Renewable Energy Resources in the Developing Countries. World Bank, Washington, D.C.

World Bank. 1981. Mobilizing Renewable Energy Technology in Developing Countries: Strengthening Local Capabilities and Research. World Bank, Washington, D.C.

Yuan, S. W. 1982. Energy, Resources and Environment. Pergamon Press, Elms ford, New York. 


\section{DISTR IBUTION}

No. of

Copies

OFFSITE

J. B. Woodard

Division 8454

Sandia National Laboratory

P.0. Box 969

Livermore, CA 94550

4 U.S. Department of Energy

Forrestal Building

1000 Independence Avenue, S.W.

Washington, D.C. 20585

Attn: H. Coleman

C. Carwide

F. Morse

M. Scheve

3 U.S. Department of Energy

1333 Broadway

0akland, CA 94612

Attn: R. W. Hughey

G. Katz

W. Lambert

2 U.S. Department of Energy

Albuquerque Operations Office

P.0. Box 5800

Albuquerque, NM 87115

Attn: J. Weiseger

G. Pappas

27 DOE Technical Information Center

J. B. Wright

Division 8450

Sandia National Laboratory

P.0. Box 969

Livermore, CA 94550

A. C. Skinrood

Division 8452

Sandia National Laboratory

P.0. Box 969

Livermore, CA 94550
No of

Copies

J. A. Dirks

Division 9454

Sandia National Laboratory

P.0. Box 969

Livermore, CA 94550

J. Swearengen

Division 9453

Sandia National Laboratory

P.0. Box 969

Livermore, CA 94550

R. Wayne

Division 8450

Sandia National Laboratory

P.0. Box 969

Livermore, CA 94550

J. Iannucci

Division 9454

P.0. Box 969

Sandia National Laboratory

Livermore, CA 94550

Acurex Corporation

485 Clyde Avenue

Mountain View, CA 94042

Attn: Howard L Morse

Advanco, Inc. 2250 East Imperial Hwy.

Suite 252

E1 Segundo, CA 90245

Attn: Byron Washom

American Public Power Association 2600 Virginia Avenue, N.W. Washington, D.C. 20037

Attn: R. E. Leber

American Solar King Corporation 7200 Imperial Drive

P.0. Drawer 7399

Waco, TX 76714-7399 
No. of

Copies

Arco

911 Wilshire Boulevard

Los Angeles, CA 90017

Attn: J. H. Caldwell, Jr.

Arco Solar Industries

21011 Warner Center Lane

Woodland Hills, CA 91367

Attn: D. N. Horgan

Arizona Public Service Company

P.0. Box 21666

Phoenix, AZ 85036

Attn: $E$. Weber

2 Babcock and Wilcox

91 Stirling Avenue

Barberton, $\mathrm{OH} 44203$

Attn: M. Seale

S. Johnson

2 Bechtel Group, Inc.

P.0. Box 3965

San Francisco, CA 94119

Attn: J. R. Darnel 1

G. Braun

Black and Veatch Consulting Engineers

P.0. Box 8405

Kansas City, M0 64114

Attn: J. C. Grosskreutz

Boeing Engineering and Construction Company

P.0. Box 3707

Seattle, WA 98124

Attn: D. H. Bartlett

Bureau of Reclamation

Department of Interior

18th and C Streets, N.W.

Washington, D.C. 20240

Attn: R. Ledzian
No. of

Copies

Cal ifornia Energy Commission

1516 North St. M/S 40

Sacramento, CA 95814

Attn: A. Jenkins

University of California

Environmental Science and Engineering

Los Angeles, CA 90024

Attn: R. G. Lindberg

Chevron U.S.A., Inc.

575 Market Street

San Francisco, CA 94105

Attn: C. W. Knowles

Combustion Engineering, Inc. 1000 Prospect Hill Road

Windsor, CT 06095

Attn: C. R. Buzzuto

Corning Glass Works

Corning, NY 14830

Attn: W. M. Baldwin

E. D. Du Pont De Nemours and Company

Information Systems Department

3140 Centre Road Building

Wilmington, DE 19898

Attn: L. A. McCoy

Edison Electric Institute

111 - 19th Street, N.W.

Washington, D.C. 20036

Attn: G. H. Lovin

El Paso Electric Company

P.0. Box 982

El Paso, TX 79946

Attn: J. E. Brown

Entech, Inc.

P.0. Box 612246

DFW Airport, TX 75261

Attn: W. J. Hesse 
No. of

Copies

Electric Power Research Institute P.0. Box 10412

Palo Alto, CA 94303

Attn: E. DeMeo

Ex-Cello-0 Corporation

Cone Drive Operations

240 E. Twelfth Street

Traverse City, MI 49684

Attn: J. G. Melvin

Exxon Enterprises, Inc.

P.0. Box 592

Florham Park, NJ 07932

Attn: T. L. Guckes

Florida Solar Energy Center

300 SR 401

Cape Canaveral, FL 32920

Attn: D. L. Black

Fluor Corporation

3333 Michelson Drive

Irvine, CA 92730

Attn: J. W. Mohlman

Ford Aerospace and Communication Corporation

3939 Fabian Way

Palo Alto, CA 94303

Attn: C. G. Hellman

Ford Motor Company

Manufacturing Processes

Laboratory

24500 Glendale

Detroit, MI 48239

Attn: R. D. Reid

Gas Research Institute

8600 W. Bryn Mawr Avenue

Chicago, IL 60731

Attn: K. G. Davidson

General Atomic Company

10955 John Jay Hopkins Drive

La Jolla, CA 92037

Attn: M. Lasarev
No. of

Copies
General Dynamics Corporation 1881 Commercenter East

San Bernardino, CA 92408

Attn: J. G. Melvin

General Electric Company

1 River Road

Schenectady, NY 12345

Attn: K. J. Daniel

General Motors

General Motors Building 12-159

Detroit, MI 48202

Attn: J. F. Britt

Georgia Institute of Technology

Atlanta, GA 30332

Attn: C. Thomas Brown

Gibbs and Hill, Inc.

393 Seventh Avenue

New York, NY 10001

Attn: R. Prieto

Grumman Aerospace Corporation

B09 - Plant 25

Bethpage, NY 11714

Attn: J.P. Alario

Gulf Science and Technology

P.0. Drawer 2038

Pittsburgh, PA 15230

Attn: A. B. King

Honeywel1, Inc.

7900 West Park Drive

McLean, VA 22102

Attn: P. A. Wyman

Institute of Gas Technology

1825 K. Street, N.W., Suite 218

Washington, D.C. 25006

Attn: D. Klass

Intersol Power Corporation

11901 West Cedar Ave.

Lakewood, C0 80228

Attn: Nick Ganiazis 
No. of

Copies

Itek Corporation

10 Maguire Road

Lexington, MA 02173

Jet Propulsion Laboratory

Mail Stop 502/201

4800 0ak Grove Drive

Pasadena, CA 91103

Attn: M. Alper

Lajet Energy Co.

3130 Antilley Road

Abilene, TX 79604

Attn: Carl Williams

Lawrence Berkeley National Laboratory

University of California

Berkeley, CA 94720

Attn: R. Bailey

Los Angeles Department of Water and Power

111 North Hope Street

Los Angeles, CA 90051

Attn: D. Chu

Luz Engineering Corporation

3940 Montclari Road, Suite 401

Birmingham, AL 35213

Attn: J. Rogozinski

2 Martin Marietta Aerospace

P.0. Box 1979, MS L0450

Denver, C0 80201

Attn: H. C. Wroton

T. L. Mayfield

The Mitre Corporation

Metrek Division

1820 Dolley Madison Boulevard

McLean, VA 22102

Attn: M. M. Scholl
No. of

Copies

McDonnell Douglas Astronautics

Company

5301 Bolsa Avenue

Huntington Beach, CA 92647

Attn: F. Duquette

NASA-Lewis Research Center

21000 Brookpark Road

Cleveland, $\mathrm{OH} 44135$

Attn: A. W. Nice

National Rural Electric Corporation Association

1800 Massachusetts Avenue

Washington, D.C. 20036

Attn: W. Prichett

New Mexico Electric Service Corporation

P.0. Box 920

Hobbs, NM 88240

Attn: R. F. Montgomery

New Mexico Solar Energy Institute

Box 3SOL, NM State University

Las Cruces, NM 88003

Attn: D. Fenton

Ohio Department of Energy

30 East Broad

Columbux, $\mathrm{OH} 43215$

Attn: A. Rahim

01 in Chemical Company

120 Long Ridge Road

Stamford, CT 06904

Attn: F. N. Christopher

Olin Chemical Company

1730 K. Street, N.W. Washington, D.C. 20006

Attn: R. E. Smith 
No. of

Copies

Overseas Private Investment Corporation

1129 Twentieth Street, N.W. Washington, D.C. 20527

Attn: C. D. Duval1, Treasurer

Pacific Gas and Electric Company

77 Beale Street

San Francisco, CA 94105

Attn: R. Molano

Pacific Gas and Electric Company 3400 Crow Canyon Road

San Ramon, CA 94526

Attn: C. Weinberg

PRC Energy Analysis Company

7600 01d Springhouse Road

McLean, VA 22102

Attn: E. F. Shaver

Power Kinetics, Inc. 1223 Peoples Ave.

Troy, NY 12180

Attn: Roger Savoy

Polydyne, Inc.

1230 Sharon Park Drive, Suite 61

Men lo Park, CA 94025

Attn: P. B. Bos

Public Service Company of Colorado

P.0. Box 840

Denver, C0 80201

Attn: E. Ellis

Public Service Company of New Mexico

P.0. Box 2267

Albuquerque, NM 87103

Attn: A. A. Akhil

The Rand Corporation

1700 Main Street

Santa Monica, CA 92401

Attn: W. Baer
No. of

Copies

Rockwell International

Energy Systems Group

8900 De Soto Avenue

Canoga Park, CA 91304

Attn: T. Springer

Sacramento Municipal Utility District

P.0. Box 15830

Sacramento, CA 95813

Attn: L. Smith

San Diego Gas and Electric Company

Mechanical Engineering

P.0. Box 1831

San Diego, CA 92112

Attn: A. Figueroa

Solarex Corporation

1335 Piccard Drive

Rockville, MD 20850

Attn: V. Sherlekar

Solar Energy Industries

- Association

1516 15th Street N.W.

Suite 520

Washington, D.C. 20005

Attn: C. LaPorta

5 Solar Energy Research Institute

1617 Cole Boulevard

Golden, C0 80401

Attn: B. Gupta

D. Hawkins

F. Krawiec

N. Murphy

J. Thorton

Solar Planning Office-West

suite 2500

333 Quebec

Denver, CO 80207

Attn: T. Prythero 
No. of

Copies

Solar Services Office

926 J. Street, Suite 201

Sacramento, CA 95816

Attn: J. Yudelson

Southern California Edison

P.0. Box 325

Daggett, CA 92327

Attn: C. Lopez

Southern California Edison

P.0. Box 800

Rosemead, CA 92807

Attn: J. N. Reeves

Spire Corporation

Patriots Park

Bedford, MA 01730

Attn: Roger Little

SRI Internationa 1

333 Ravenswood Avenue

Menlo Park, CA 94025

Attn: P. M. Newgard

Standard $0 i 1$ of California

555 Market Street, Room 1104

San Francisco, CA 94119

Attn: S. G. Gibb

Stearns-Roger

P.0. Box 5888

Denver, CO 80217

Attn: W. R. Lang

Stone and Webster Engineering

Corporation

P.0. Box 1214

Boston, MA 02107

Attn: R. W. Kuhr

Stone and Webster Engineering

Corporation

7501 Marin Drive

Englewood, CO 80460

Attn: A. J. Cornish
No. of

Copies

4 U.S. AID

Directorate for Energy and

Natural Resources

Bureau for Science and

Technology

Washington, D.C. 20523

Attn: J. Vandevjyn, Agency Director

S. Patton, Special Assistant

S. Sweitzer

R. Archer

United States Congress

Office of Technical Assessment Washington, D.C. 20510

Attn: J. Furber

U.S. Bureau of Reclamation

Interior Building

Washington, D.C. 20240

Attn: E. H. T. Curtis

University of Houston

Solar Energy Laboratory

4800 Calhoun

Houston, TX 77704

Attn: A. F. Hildebrandt

University of Kansas

2291 Irving Hill Road

Lawrence, KS 66045

Attn: R. R. Riordon

Westinghouse Electric Corporation Advanced Energy Systems Division P.0. Box 10864

Pittsburgh, PA 15236

Attn: J. R. Maxwell 
ONSITE

DOE Richl and Operations office

H. E. Ransom

R. K. Stewart

18 Pacific Northwest Laboratory

W. B. Ashton

D. L. Brenchley

J. C. Easterling (5)

R. E. Fleischman

S. C. Hauser

R. A. Hutchinson

T. A. Williams

Publishing Coordination MH (2)

Technical Information (5) 
• 